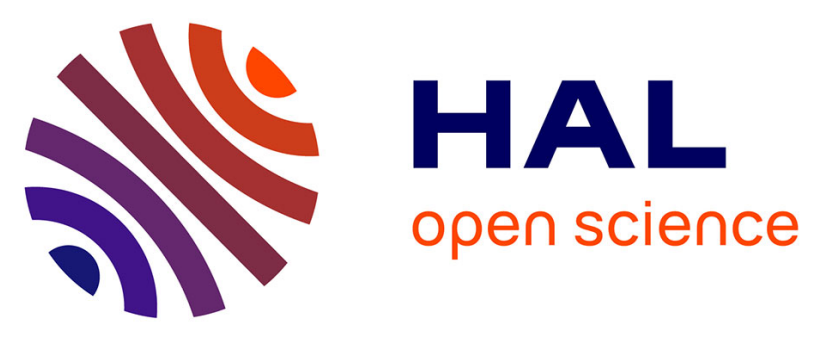

\title{
Replication of the linear chromosomal DNA from the centrally located oriC of Streptomyces ambofaciens revealed by PFGE gene dosage analysis
}

\author{
Gilles Fischer, Anne-Catherine Holl, Jean Nicolas Volff, Dominique
}

Vandewiele, Bernard Decaris, Pierre Leblond

\section{To cite this version:}

Gilles Fischer, Anne-Catherine Holl, Jean Nicolas Volff, Dominique Vandewiele, Bernard Decaris, et al.. Replication of the linear chromosomal DNA from the centrally located oriC of Streptomyces ambofaciens revealed by PFGE gene dosage analysis. Research in Microbiology, 1998, 149 (3), pp.203210. 10.1016/S0923-2508(98)80080-6 . hal-01658988

\section{HAL Id: hal-01658988 \\ https://hal.univ-lorraine.fr/hal-01658988}

Submitted on 8 Dec 2017

HAL is a multi-disciplinary open access archive for the deposit and dissemination of scientific research documents, whether they are published or not. The documents may come from teaching and research institutions in France or abroad, or from public or private research centers.
L'archive ouverte pluridisciplinaire HAL, est destinée au dépôt et à la diffusion de documents scientifiques de niveau recherche, publiés ou non, émanant des établissements d'enseignement et de recherche français ou étrangers, des laboratoires publics ou privés. 


\title{
Replication of the linear chromosomal DNA from the centrally located oriC of Streptomyces ambofaciens revealed by $\mathrm{PFGE}$ gene dosage analysis
}

\author{
G. Fischer ${ }^{(1)}$, A.C. Holl ${ }^{(2)}$, J.N. Volff ${ }^{(3)}$, D. Vandewiele ${ }^{(4)}$, B. Decaris ${ }^{(1)}$ and P. Leblond ${ }^{(1)\left({ }^{*}\right)}$ \\ (')Laboratoire de Génétique et Microbiologie, Unité associée INRA 952, Faculté des Sciences, \\ Université Henri Poincaré, Nancy 1, B.P. 239, F-54506 Vandouvre-lès-Nancy (France), \\ ${ }^{(2)}$ Laboratoire de Génétique et évolution des populations, Université des Sciences \\ et Technologies de Lille, Bâtiment SN2, 59655 Villeneuve d'Ascq cedex (France), \\ ${ }^{(3)}$ Physiological Chemistry I, Theodor Boveri Institute for Biosciences (Biocenter), \\ University of Wuerzburg, Am Hubland, 97097 Wuerzburg (Germany), and \\ ${ }^{(4)}$ Building 6, Room 1A15, NICHD, NIH, 9000 Rockville Pike, Bethesda, MD 20892-2723 (USA)
}

\section{SUMMARY}

From a cosmid clone of Streptomyces ambofaciens containing the dnaA and gyrAB genes, a 2.7-kb self-replicating DNA fragment containing the chromosome replication origin oriC was isolated. This cosmid was previously mapped physically to a region near the middle of the 8-Mb linear chromosomal DNA. A pulsed-field gel electrophoresis time-course analysis revealed that sequences flanking oriC were overrepresented relative to the rest of the chromosomal DNA during rapid growth, indicating that this origin is active. In addition, the terminal regions of the chromosomal DNA showed a slight overrepresentation at the onset of stationary phase.

Key-words: Streptomyces ambofaciens, oriC; Linear chromosome, Replication, PFGE.

\section{INTRODUCTION}

A physical map of the linear chromosome of three strains of Streptomyces ambofaciens has recently been constructed (Leblond et al., 1996). The DNA sequences of the chromosome ends are inversely repeated over $210 \mathrm{~kb}$ in strain DSM40697, an unusually long distance. The 5' ends of the chromosome are covalently asso- ciated with proteins. This kind of structure has been called an "invertron" by Sakaguchi (1990) and seems to be typical of Streptomyces genomes (Lezhava et al., 1995; Lin et al., 1993; Pandza et al., 1997; Redenbach et al., 1996). Two different replication mechanisms have been demonstrated for invertrons. (1) Replication of $\Phi 29$ of Bacillus subtilis, by a bacteriophage-encoded DNA polymerase, is primed at both ends by the terminal 
proteins; it proceeds over the whole length of the phage DNA, resulting in semi-conservative replication without formation of Okazaki fragments (reviewed in Salas, 1991). (2) The linear plasmid pSLA2 of Streptomyces rochei has a functional centrally located, bidirectional replication origin; most of pSLA2 is replicated bidirectionally from the central origin. Protein-primed DNA synthesis contributes only about 280 nucleotides at the end of the lagging strands (Chang and Cohen, 1994).

The chromosome replication origins (oriC) of Streptomyces lividans 66 and Streptomyces coelicolor A3(2) were mapped close to the middle of the chromosome associated with $\operatorname{dnaA}$ and $g y r B$ genes (Musialowski et al., 1994). In the latter species, gene dosage experiments indicated that oriC is active during vegetative growth (Calcutt and Schmidt, 1992; Musialowski et al., 1994; Zakrzewska-Czerwinska and Schrempf, 1992). Here we show that $S$. ambofaciens also has an oriC locus near the middle of the chromosome and that replication proceeds from this locus by a bidirectional mechanism.

\section{MATERIALS AND METHODS}

\section{Bacterial strains}

S. ambofaciens DSM40697 (Hütter, 1967), S. ambofaciens ATCC 15154 (Pinnert-Sindico et al., 1955), and S. lividans TK21 (Hopwood et al., 1985) were the Streptomyces strains used in this work. Escherichia coli HB101 (Boyer and Roulland-Dussoix, 1969; Boehringer Mannheim, Germany) and E. coli GM33 (Yanish-Perron et al., 1985; Stratagene, USA) were used as hosts for the cloning experiments.

\section{Media, culture conditions and transformation}

$E$. coli cells were grown in Luria-Bertani medium, according to Sambrook et al. (1989) and transformed by electroporation (Biorad, Hercules, Calif., USA). Streptomyces were grown at $30^{\circ} \mathrm{C}$ in yeast extract malt extract (YEME) medium and transformed according to Hopwood et al. (1985).

\section{DNA purification, Southern analysis}

Plasmid extractions were performed according to Sambrook et al. (1989) for E. coli. For Streptomyces, plasmid extractions and subsequent purifications by caesium chloride-ethidium bromide gradients were carried out according to Hopwood et al. (1985) and Sambrook et al. (1989), respectively. Genomic DNA extractions and restriction analyses were carried out as previously described (Demuyter et al., 1988 ; Leblond et al., 1996). Restriction enzymes and molecular biology reagents were purchased from New England Biolabs (USA) and Boehringer Mannheim (Mannheim, Germany).

For Southern transfers, "Hybond-N" membranes (Amersham, UK) and either the "Vacugene" system (LKB, Sweden) or the Smith and Summers method (1980) were used. For colony transfers, "Qiabrane" membranes (Qiagen, Germany) were used according to the instructions of the supplier. DNA (purified or in agarose) was labelled with digoxigenin (Dig)labelled dUTP, and specific hybrids were detected using the "DIG DNA" labelling and detection kit (Boehringer Mannheim). Alternatively, probes were labelled with ${ }^{32} \mathrm{P}$ according to Demuyter $e t$ al., (1988) using the "Multiprime" labelling system (Amersham). Hybridizations were performed at $68^{\circ} \mathrm{C}$ corresponding to a stringency consistent with the detection of $100 \%$ homologues.

\section{Gene bank preparation}

An $S$. ambofaciens cosmid gene library was constructed using the "Packagene" kit (Promega, USA). DNA was partially PstI-digested, ligated into the PstI site of pHC79 (Hohn and Collins, 1980; Boehringer Mannheim) and introduced into $E$. coli HB101.

\section{Cloning of oriC from S. ambofaciens}

The non-replicating 1.1-kb $B c l$ fragment of plasmid pIJ702 (Hopwood et al., 1985) containing the thiostrepton resistance gene (tsr) was purified from an agarose gel using the Geneclean ${ }^{\mathrm{TM}}$ procedure (Bio 101, La Jolla, CA, USA) and ligated to Bcll-digested

\footnotetext{
ATCC $=$ American Type Culture Collection.

DSM = Deutsche Sammlung von Mikroorganismen.

kb $=$ kilobase.

$\mathrm{Mb} \quad=$ megabase.

PFGE $=$ pulsed-field gel electrophoresis.

YEME = yeast extract malt extract.
} 
DNA of pNSA2001, a cosmid harbouring the $S$. ambofaciens oriC region. Plasmid pNSA2001 was isolated from $E$. coli GM33 [Dam-] to allow cleavage with $B c i l$ restriction. The ligation mixture was introduced by transformation into $S$. lividans TK21 protoplasts, and thiostrepton-resistant colonies were selected $(50 \mu \mathrm{g} / \mathrm{ml}$; Hopwood et al., 1985).

\section{PFGE and gene dosage analysis}

Pulsed-field gel electrophoresis (PFGE) experiments were carried out according to Leblond et al. (1993). Electrophoresis was performed in a contourclamped homogeneous electric fields systern (CHEF, Biorad; Chu et al., 1986). Gene dosage experiments were carried out at different growth times. After growth of $S$. ambofaciens DSM40697 in YEME medium (Hopwood et al., 1985) growth curves were calculated, followed by measuring of the DNA concentrations as described by Burton (1956). For each AseI fragment, the intensity was measured from a densitometric reading using the "GelDoc 1000" system and the Molecular Analyst ${ }^{\mathrm{TM}}$ software (Biorad), and was expressed relative to its molecular weight.

\section{RESULTS}

\section{Cloning of the gyrAB-dnaA region of the S. ambofaciens DSM40697}

A gene library was constructed from partially PstI-digested S. ambofaciens DSM40697 ligated to pHC79 and propagated into $E$. coli HB101. Among 2,000 recombinant clones, 11 hybridized to the gyrB probe pLST182 (Thiara and Cundliffe, 1993). Two cosmids, pNSA2001 and pNSA2002, overlapping only by a $1.7-\mathrm{kb}$ Pst I fragment, were selected for further analysis (fig. 1). The 1.7-kb Pstl fragment hybridizing to pLST182 was sequenced partially from both ends (389 and 264 nucleotides, Genbank accession numbers AF004299 and AF004298, respectively). The amino acid sequences deduced from the right and left ends resemble, respectively, GyrA and GyrB proteins of S. coelicolor A3(2) (Calcutt, 1994), closely related to $S$. ambofaciens. Both genes read in the same direction. Hybridization with the 1.1-kb pFF911-derived $S$. lividans dnaA (Musialowski et al., 1994) probe located this gene to a 4.4-kb BamHI fragment upstream of the gyrAB sequences in pNSA2001 (fig. 1).
Isolation of oriC of $\mathbb{S}$. ambofaciens on a $2.7-\mathrm{kb}$ self-replicating DNA fragment

Since oriC of $S$. ambofaciens was expected to be close to dnaA, within pNSA2001, we undertook the subcloning of pNSA2001 recom binant cosmid (inserted DNA circa $35 \mathrm{~kb}$ ) with $B c l l$ in order to isolate the DNA fragment conferring autonomous replication. Plasmid pNSA2001 $\mathrm{Bcll}$ fragments were ligated to the $1.1-\mathrm{kb} \mathrm{Bcll} t s r$ (thiostrepton resistance) fragment (see "Materials and methods"). The ligation mixture was introduced into S. lividans TK21. Forty thiostrepton-resistant clones were isolated, and for two of them the extrachromosomal content was studied by caesium-chloride gradient analysis. Both of them contained pNSA2004, a 3.8-kb circular molecule consisting of a $2.7-\mathrm{kb} \mathrm{Bcll}$ fragment from pNSA2001 and the $1.1-\mathrm{kb} \mathrm{BclI} t s r$ fragment. The 2.7-kb fragment is wholly contained within the $4.4 \mathrm{~kb}-$ BamHI fragment, as shown by hybridization of pNSA2004 DNA onto BamHIdigested DNA of pNSA2001 (fig. 1). In addition, the former fragment hybridized to the dnaA probe pFF911 (Musialowski et al., 1994) and to pUOR2, which contains oriC of S. lividans (Zakrzewska-Czerwinska and Schrempf, 1992). Furthermore, pIJ702 tsr DNA (1.1-kb $B c l$ fragment) was used as a probe onto Southern blots of total DNA of one of the $S$. lividans TK21 tsr-resistant transformants digested with restriction enzymes cutting once in the $t s r$ sequence but not in the $2.7-\mathrm{kb}$ insert. For two such enzymes (EcoRV and ClaI), only a DNA fragment whose size corresponded to the linearized extrachromosomal form of the plasmid $(3.8 \mathrm{~kb})$ was revealed by the probe. No other fragment that could have corresponded to integrated forms of the plasmid was observed (data not shown). This result ruled out apparent auionomous replication by integration-excision process.

\section{Time-course gene dosage in $S$. ambofaciens}

The chromosomal localization of oriC was determined by probing of $S$. ambofaciens DNA 


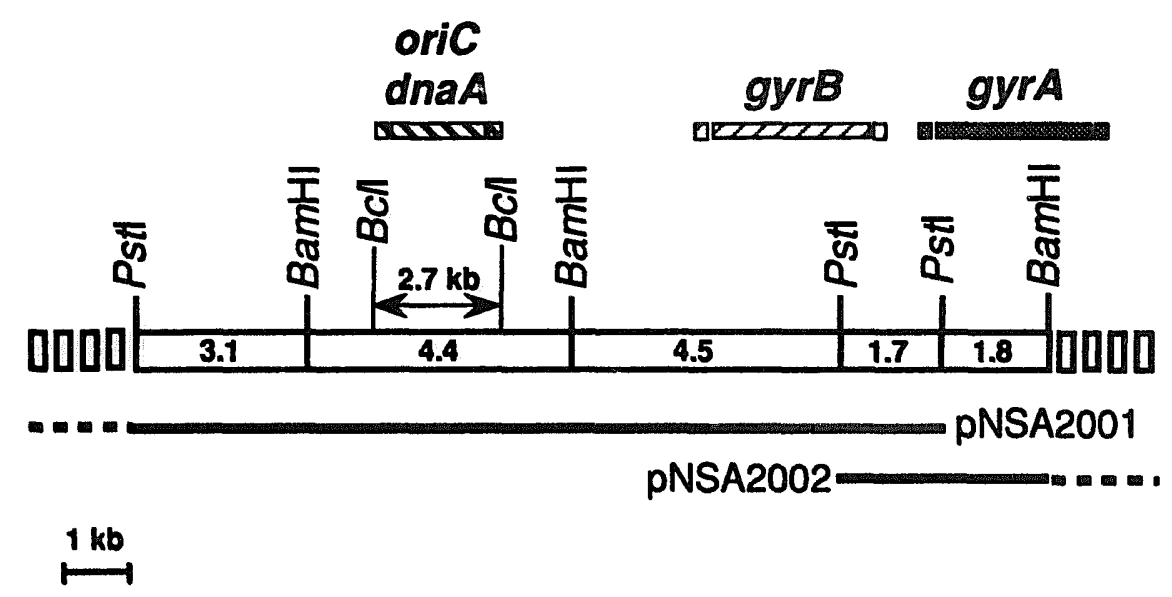

Fig. 1. Restriction map of the oriC region of $S$. ambofaciens DSM40697.

Cosmids pNSA2001 and pNSA2002 are partially represented. Sizes are in kilobases. The 2.7-kb $B$ cll fragment (flanked by the arrows) containing oriC and $d n a A$ is totally included in the 4.4-kb BamHI fragment, but was not precisely mapped.

separated by PFGE with labelled pNSA2001. The locus oriC mapped to the AseI-C fragment, $1,050 \mathrm{~kb}$, (AseI-C", 1,100 kb, in strain ATCC 15154; fig. 2) and a 460-kb BfrI fragment which overlaps AseI-C and -H by approximately $345 \mathrm{~kb}$ and $125 \mathrm{~kb}$, respectively (Berger et al., 1996). Gene dosage experiments were carried out in order to test the functionality of oriC. Aliquots of an S. ambofaciens DSM40697 culture were taken at different times of the growth curve and analysed by PFGE (fig. 3). The relative intensity of each DNA band was measured from densitometric readings (see "Materials and methods"). The relative intensities of AseI-C containing oriC and of the neighbouring fragments AseI-H and AseI-I was significantly higher than the relative intensities of the other fragments during exponential growth phase (fig. 3). The decrease in relative intensity of the restriction fragments corresponding to the higher masses (AseI A and B) was interpreted as random degradation during DNA preparation (Leblond et al., 1990). To account for this degradation, ratios were calculated between DNA fragments of the same size range, assuming an equivalent degradation. The intensity ratios AseI-C/D (D corresponding to one chromosomal extremity; fig. 2) and $C / E$ were 2.4 and 2.3 at $20 \mathrm{~h}$ of growth, respectively.
Similarly, ratios $\mathrm{H} / \mathrm{J}$ and $\mathrm{I} / \mathrm{J}$ were 1.6 at $20 \mathrm{~h}$. In contrast, the ratios $\mathrm{C} / \mathrm{D}, \mathrm{C} / \mathrm{E}, \mathrm{H} / \mathrm{J}$ and $\mathrm{I} / \mathrm{J}$ decreased to $1.0,1.1,1.0$ and 0.9 at $148 \mathrm{~h}$, respectively (fig. 3). The overrepresentation of fragments Ase I-C, $-\mathrm{H}$ and $-\mathrm{I}$ is always observed when DNA is prepared during the exponential growth phase. Our early PFGE analysis of the $S$. ambofaciens genome concluded that doublets were present (Leblond et al., 1990), while mapping experiments showed that they were single bands. Thus, these data support the hypothesis of reinitiations of the chromosomal replication at this point during rapid growth.

Bidirectional processing of oriC was demonstrated taking advantage of the restriction polymorphism between the two strains DSM40697 and ATCC 15154 (Leblond et al., 1996). In strain ATCC 15154, fragment AseI-N" replaces fragment B of strain DSM40697 (fig. 2). The intensity ratios AseI-N"/L" and M"/L" were 1.5 and 2.0 at $20 \mathrm{~h}$ of growth, respectively. The unbalanced position of oriC relative to N" and M" (N" and $M$ " are distant from oriC by at least 750 and $280 \mathrm{~kb}$, respectively; fig. 2) could explain the slightly fainter overrepresentation of $\mathrm{N}$ " relative to that of M". Fragments AseI-J" (280 kb) and K" $(260 \mathrm{~kb})$ comigrated in this experiment and were left out. 


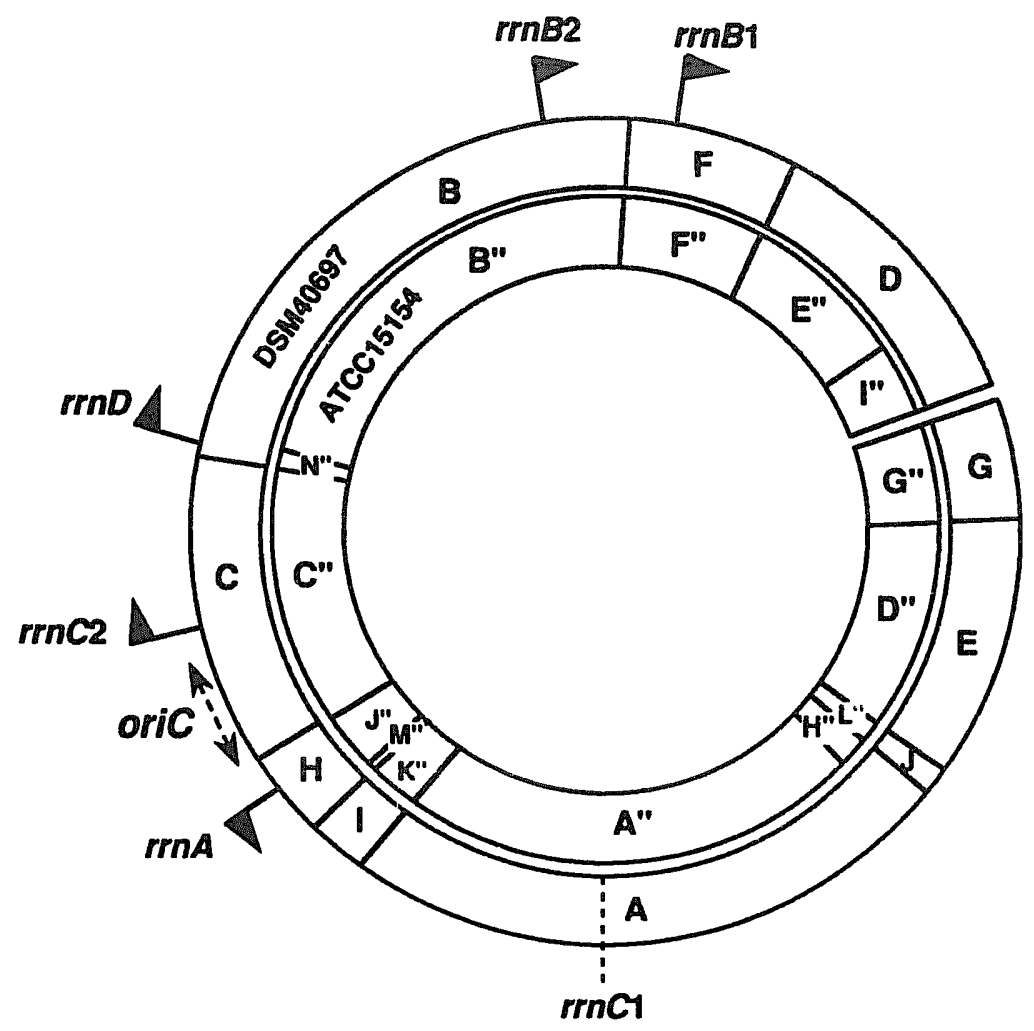

Fig. 2. Genetic organization of the chromosome of $S$. ambofaciens.

AseI restriction maps of $S$. ambofaciens strains DSM40697 (outer circle) and ATCC 15154 (inner circle) according to Leblond $e t$ al. (1996). The dotted arrow delimits the localization of oriC. The transcriptional orientation of the $r r n$ operons according to Berger et al. (1996) is symbolized by a black flag.

Overrepresentation of the terminal fragments at the onset of the stationary phase

In $S$. ambofaciens, the densitometric analysis revealed an overrepresentation of the fragments corresponding to the extremities of the chromosomal DNA between 36 and $60 \mathrm{~h}$. At $60 \mathrm{~h}$, the ratios $\mathrm{D} / \mathrm{C}$ and $\mathrm{D} / \mathrm{E}$ were 1.4 and 1.2 , respectively (fig. 3). Similarly, the ratio G/F was 1.2 at $60 \mathrm{~h}$. This phenomenon is reproducibly observed, although the values vary with the experiment. This indicated a noticeable overrepresentation of fragments $D$ and $G$, corresponding to the ends of the chromosomal DNA (fig. 2).

\section{DISCUSSION}

A locus exhibiting an oriC-like organization similar to oriC from S. lividans 66 and $S$. coeli- color A3(2) was isolated from S. ambofaciens DSM40697 (Calcutt and Schmidt, 1992; Zakrzewka-Czerwinska and Schrempf, 1992). The localization of the gyrAB genes close to oriC observed in Streptomyces was also reported in several other bacteria such as B. subtilis, Staphylococcus aureus, Borrelia burgdorferi and Mycoplasma pneumoniae, but it was different in $E$. coli (Reece and Maxwell, 1991).

The localization of oriC was previously reported in S. coelicolor (Kieser et al., 1992) and S. lividans (Leblond et al., 1993) to map approximately to the middle of the linear $8 \mathrm{Mb}$ chromosomal DNA as in S. ambofaciens (Berger et al., 1996) but not in $S$. rimosus (34 to $44 \%$ from one end, Pandzá et al., 1997).

Several lines of evidence showed that oriC functions bidirectionally in $S$. ambofaciens during the exponential phase. First, a $2.7-\mathrm{kb}$ fragment 


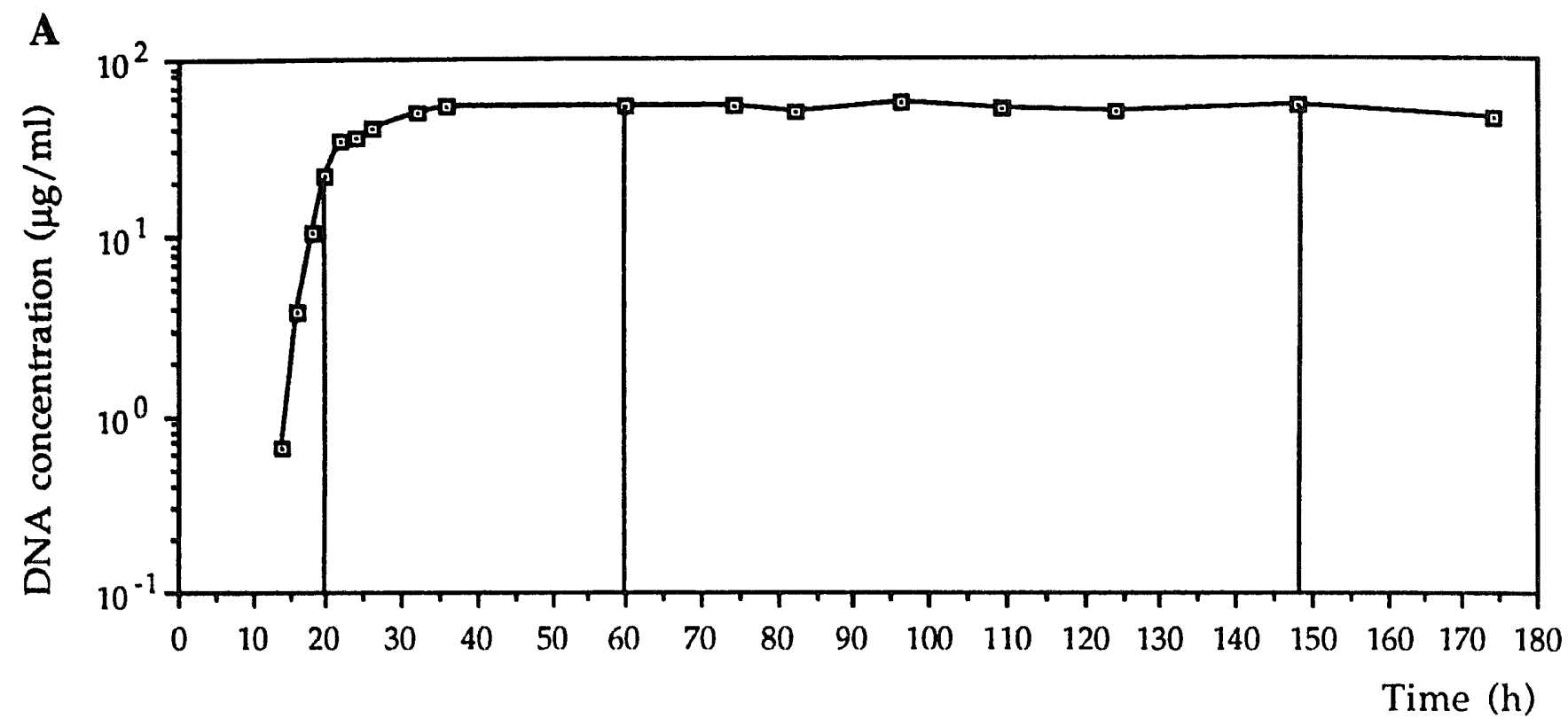

B

$20 \mathrm{~h}$

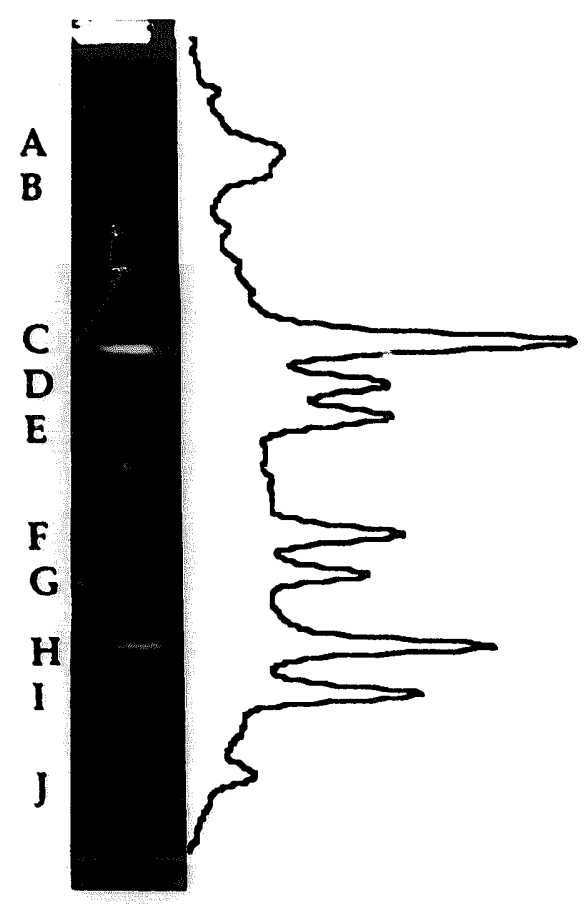

$60 \mathrm{~h}$

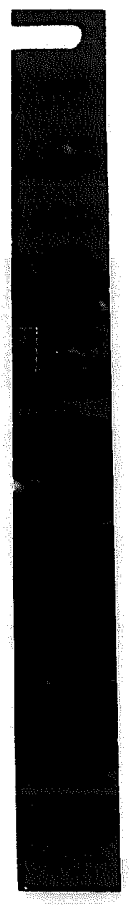

$148 \mathrm{~h}$

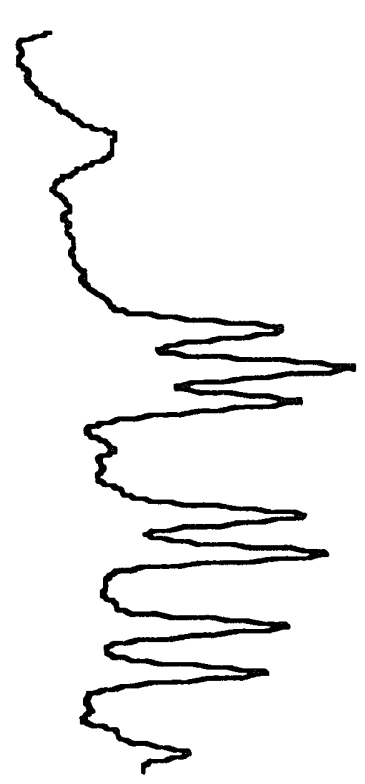

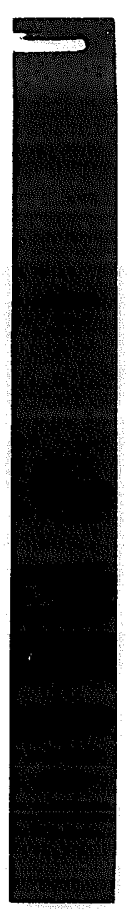

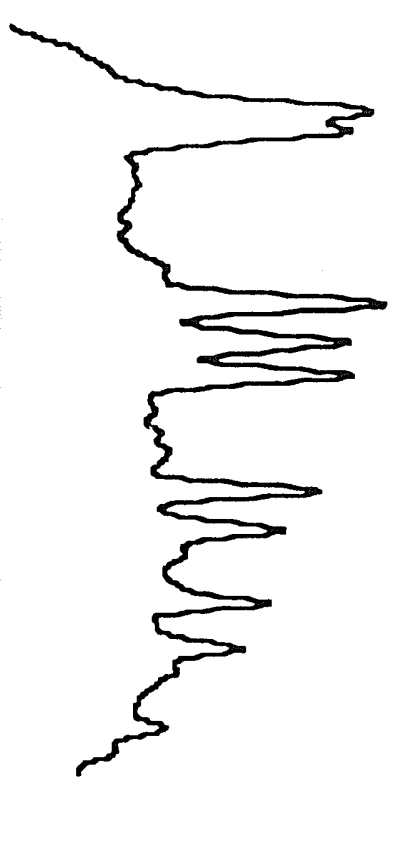

Fig. 3. PFGE gene dosage experiments during growth.

Growth curve (A) and DNA concentration measurements (B) of S. ambofaciens DSM40697 are described in "Materials and methods". Vertical lines in A indicate times (h) when PFGE analysis was carried out. PFGE running conditions were $0.85 \%$ agarose gel, $200 \mathrm{~V}$ for $24 \mathrm{~h}$ with ramped pulse times from 40 to $160 \mathrm{~s}$. Nomenclature of fragments, A-J, is according to Leblond et al. (1996). Densitometric readings were carried out using "GelDoc 1000" and Molecular Analyst $^{\text {TM }}$ (Biorad). 
showed autonomous replication in S. lividans TK21 and hybridized to both $d n a A$ and oriC (from $S$. lividans). Secondly, PFGE time-course experiments showed that when mycelia were harvested from rapidly growing cultures, the regions flanking the oriC locus were overrepresented. This data strongly suggested that reinitiation of replication takes place at this locus during exponential growth. A similar strategy based on gene dosage experiments led Musialowski et al. (1994) to the same conclusion for the centrally located oriC locus of the $S$. coelicolor chromosome. Our approach consitutes a rapid and simple way to initiate the study of the replication mechanisms and could be applied in other organisms.

In addition, the cloning of the rrn genes was recently achieved in S. ambofaciens DSM40697 (Berger et al., 1996). These experiments enabled the precise positioning of the $r r n$ loci relative to the physical map and the determination of their transcriptional orientation. For five of six of them it was found to be divergent from oriC (fig. 2). Considering that highly expressed genes are usually transcribed in the direction of the migration of the replication forks (Brewer, 1988), altogether, these results show that the linear chromosome of $S$. ambofaciens would be essentially replicated by a bidirectional replication mechanism from oriC towards the extremities.

Furthermore, at the onset of the stationary phase, a slight overrepresentation of the terminal fragments (flanking the ends of the chromosome) was noticed. Overrepresentation could be interpreted as reinitiation of replication in the terminal regions. DNA replication might be initiated either from the chromosomal ends and require the terminal proteins as primers, or from subterminal loci by a bidirectional mechanism. Secondly, overrepresentation of a DNA fragment might reveal its relative resistance to DNA degradation. DNA degradation could happen in vivo during the transition phase or during DNA preparation. These data could support the existence of a "racket frame" structure (Sakaguchi, 1990) keeping the terminal regions including terminal inverted repeats associated. This structure might be related to the high structural instability occurring in the terminal regions of the linear chromosomal DNA in $S$. ambofaciens (Fischer et al., 1997).

\section{Acknowledgements}

We are grateful to T. Kieser for his help with the preparation of the manuscript. Many thanks to E. Cundliffe, F. Flett and $\mathrm{H}$. Schrempf for giving us some of the plasmids used in this work.

Réplication de l'ADN chromosomique linéaire de Streptomyces ambofaciens à partir de l'origine de réplication oriC localisée au milieu

du chromosome: mise en évidence par dosage de gènes en PFGE

L'origine de réplication principale du chromosome de Streptomyces ambofaciens a été isolée sur un fragment d'ADN de $2,7 \mathrm{~kb} B c l$ à partir d'un cosmide recombinant contenant les gènes $d n a A$ et gyrAB. Ce cosmide a été localisé dans une région située approximativement au milieu de l'ADN chromosomique linéaire de $8 \mathrm{Mb}$. L'analyse de l'intensité relative des fragments de restriction séparés par électrophorèse en champs pulsés en fonction du temps de croissance montre que les séquences proches d'oriC sont sur-représentées en phase exponentielle de croissance. Ce résultat indique que cette origine de réplication est active. Par ailleurs, à l'entrée de la phase stationnaire de croissance, les régions terminales de l'ADN chromosomique présentent une légère sur-représentation par rapport au reste du chromosome.

Mots-clés : Streptomyces ambofaciens, oriC; ADN linéaire, Réplication, PFGE.

\section{References}

Berger, F., Fischer, G., Kyriacou, A., Decaris, B. \& Leblond, P. (1996), Mapping of the ribosomal operons on the linear chromosomal DNA of Streptomyces ambofaciens DSM40697. FEMS Microbiol. Lett. 143, 167-173.

Boyer, H.W. \& Roulland-Dussoix, D. (1969), A complementation analysis of the restriction and modification of DNA in Escherichia coli. J. Mol. Biol., 41, 459. 472.

Brewer, B.J. (1988), When polymerases collide: replication and the transcriptional organization of the E. coli chromosome. Cell, 53, 679-686.

Burton, K. (1956), A study of the conditions and mecha- 
nism of the diphenylamine reaction for the colorimetric reaction estimation of deoxyribonucleic acid. Biochem. J., 9, 652-656.

Calcutt, M.J. (1994), Gene organization in the dnaA-gyrA region of the Streptomyces coelicolor chromosome. Gene, 151, 23-28.

Calcutt, M.J. \& Schmidt, F.J. (1992), Conserved gene arrangement in the origin region of the Streptomyces coelicolor chromosome. J. Bacteriol., 174, 32203226.

Chang, P.-C. \& Cohen, S.N. (1994), Bidirectional replication from an internal origin in a linear Streptomyces plasmid. Science, 265, 952-954.

Chu, G., Vollrath, D. \& Davis, R.W. (1986), Separation of large DNA molecules by contour-clamped homogeneous electric fields. Science, 234, 1582-1585.

Demuyter, P., Leblond, P., Decaris, B. \& Simonet, J.-M. (1988), Characterization of two families of spontaneously amplifiable units of DNA in Streptomyces ambofaciens. J. Gen. Microbiol., 134, 2001-2007.

Fischer, G., Decaris, B. \& Leblond, P. (1997), Occurrence of deletions, associated with genetic instability in Streptomyces ambofaciens, is independent of the linearity of the chromosomal DNA. J. Bacteriol., 179, 4553-4558.

Hohn, B. \& Collins, B. (1980), Small cosmid for efficient cloning of large DNA fragments. Gene, 11, 291-298.

Hopwood, D.A., Bibb, M.J., Chater, K.F., Kieser, T., Bruton, C.J., Kieser, H.M., Lydiate, D.J., Smith, C.J., Ward, J.M. \& Schrempf, H. (1985), Genetic manipulation of Streptomyces: a laboratory manual. John Innes Foundation, Norwich, England.

Hütter, R. (1967), Systematik der Streptomyceten. Karger Verlag, Basel.

Kieser, H.M., Kieser, T. \& Hopwood, D.A. (1992), A combined genetic and physical map of the Streptomyces coelicolor A3(2) chromosome. J. Bacteriol., 174, 5496-5507.

Leblond, P., Fischer, G., Francuu, F.X., Berger, F., Guérineau, M. \& Decaris, B. (1996), The unstable region of Streptomyces ambofaciens includes $210 \mathrm{~kb}$ terminal inverted repeats flanking the extremities of the linear chromosome. Mol. Microbiol., 19, 261271.

Leblond, P., Francou, F.X., Simonet, J.-M. \& Decaris, B. (1990), Pulsed-field gel analysis of the genome of Streptomyces ambofaciens strains. FEMS Microbiol. Lett., 72, 79-88.

Leblond, P., Redenbach, M. \& Cullum, J. (1993), Physical map of the Streptomyces lividans 66 genome and comparison with that of the related strain Streptomyces coelicolor A3(2). J. Bacteriol., 175, 34223429.

Lezhava, A., Mizukami, T., Kajitani, T., Kameoka, D.,
Redenbach, M., Shinkawa, H., Nimi, O. \& Kinashi, H. (1995), Physical map of the linear chromosome of Streptomyces griseus. J. Bacteriol., 177, 6492-6498.

Lin, Y.-S., Kieser, H.M., Hopwood, D.A. \& Chen, C.W. (1993), The chromosomal DNA of Streptomyces lividans is linear. Mol. Microbiol., 10, 923-933.

Musialowski, M.S., Flett, F., Scott, G.B., Hobbs, G., Smith, C.P. \& Oliver, S.G. (1994), Functional evidence that the principal DNA replication origin of the Streptomyces coelicolor chromosome is close to the dnaA-gyrB region. J. Bacteriol., 176, 5123-5125.

Pandza, K., Pflazer, G., Cullum J. \& Hranueli, D. (1997), Physical mapping shows that the unstable oxytetracycline gene cluster of Streptomyces rimosus lies close to one end of the linear chromosome. Microbiology, 143, 1496-1501.

Pinnert-Sindico, S., Ninet, L., Preud'homme, J. \& Cosar, C. (1955), A new antibiotic: spiramycin. Antibiot. An. 1954-1955, 724-727.

Redenbach, M., Kieser, H.M., Denapaite, D., Eichner, A., Cullur, J., Kinashi, H. \& Hopwood, D.A. (1996), A set of ordered cosmids and a detailed genetic and physical map for the $8 \mathrm{Mb}$ Streptomyces coelicolor A3(2) chromosome. Mol. Microbiol., 21, 77-96.

Reece, R.J. \& Maxwell, A. (1991), DNA gyrase: structure and function. CRC Crit. Rev. Biochem. Mol. Biol., 26, 335-375.

Sakaguchi, K. (1990), Invertrons, a class of structurally and functionally related genetic elements that include linear DNA plasmids, transposable elements, and genomes of adeno-type viruses. Microbiol. Rev., 54, 66-74.

Salas, M. (1091), Protein-priming of DNA replication. Annu. Rev. Biochem., 60, 39-71.

Sambrook, J., Fritsch, E.F. \& Maniatis, T. (1989), Molecular cloning: a laboratory manual. $2^{\text {nd }} \mathrm{ed}$. Cold Spring Harbor Laboratory, Cold Spring Harbor, New-York.

Smith, G.E. \& Summers, M.D. (1980), The bidirectional transfer of DNA and RNA to nitrocellulose or diazobenzyloxymethyl paper. Anal. Biochem., 109, 123129.

Thiara, A.S. \& Cundliffe, E. (1993), Expression and analysis of two gyrB genes from the novobiocin producer, Streptomyces sphaeroides. Mol. Microbiol., 8, 495-506.

Yanisch-Perron, C., Viera, J. \& Messing, J. (1985), Improved M13 phage cloning vectors and host strains: nucleotide sequences of the M13mp18 and pUC19 vectors. Gene, 33, 103-199.

Zakrzewka-Czerwinska, J. \& Schrempf, H. (1992), Characterization of an autonomously replicating region from the Streptomyces lividans chromosome. J. Bacteriol., 174, 2688-2693. 